\title{
Nanotechnology in Metformin Delivery: Fasting Blood Glucose and Neutrophil-Lymphocyte Ratio of Diabetic Rat Model
}

\author{
David Pakaya ${ }^{1 *}$, Laurents Christovel Iban Demen ${ }^{2}$, Haerani Harun ${ }^{3}$, Sarifuddin Anwar ${ }^{4}$, \\ Gabriella Bamba Ratih Lintin ${ }^{4}$ \\ ${ }^{1}$ Department of Histology Faculty of Medicine Universitas Tadulako, Palu City, Central Sulawesi, Indonesia \\ ${ }^{2}$ Medical Student of Faculty of Medicine Universitas Tadulako, Palu City, Central Sulawesi, Indonesia \\ ${ }^{3}$ Department of Clinical Pathology Faculty of Medicine Universitas Tadulako, Palu City, Central Sulawesi, Indonesia \\ ${ }^{4}$ Department of Anatomy Faculty of Medicine Universitas Tadulako, Palu City, Central Sulawesi, Indonesia
}

\begin{abstract}
DATE OF ARTICLE:
Received: 18 Nov 2021

Reviewed: 31 Dec 2021

Revised: 24 Jan 2022

Accepted: 26 Jan 2022

CORRESPONDENCE:

david_pakaya@untad.ac.id

DOI:

10.18196/mmjkk.v21i2.13358

Abstract: Diabetes Mellitus (DM) is a chronic inflammatory disease characterized by hyperglycemia and increasing the neutrophil-lymphocyte ratio (NLR). Metformin has been widely used to treat hyperglycemia. Metformin nanoparticles can improve bioavailability and may reduce inflammation. This study aims to analyze the effectiveness of metformin nanoparticles delivery through fasting blood glucose (FGB) level and NLR in the diabetic rat model. This study used 16 white male Wistar rats, 8 weeks of age, and body weight (BW) 250-350 grams. The streptozotocin (STZ) $40 \mathrm{mg} / \mathrm{kg} \mathrm{BW}$ were injected i.p. Rats were divided into 4 groups; K1: normal control; K2: negative control (diabetes model); K3: diabetes model treated with metformin $100 \mathrm{mg} / \mathrm{Kg} \mathrm{BW}$; K4: diabetes model treated with nanoparticle metformin $100 \mathrm{mg} / \mathrm{kg}$ BW. Blood analysis tests were conducted using the Pentra hematology analyzer. Data were analyzed using the Graphpad Prism program with the nonparametric Kruskal

TYPE OF ARTICLE:

Research Wallis test. The $\mathrm{K} 3$ group showed a periodical decrease in FBG level from day 7 to day 28 by $122 \pm 11.31 \mathrm{mg} / \mathrm{dL}$, and the mean NLR value was $0.48 \pm 0.3 \times 10^{3} / \mathrm{uL}$. Group of K4 periodically decreased in FBG level, indicating that it was closer to normal than K3. The result showed that at day $28.79 \pm 15.39 \mathrm{mg} / \mathrm{dL}$, the mean NLR value slightly increased compared to the $\mathrm{K} 3$ group by $0.54 \pm 0.3 \times 10^{3} / \mathrm{uL}$. The statistical tests showed a significant difference between the level of FBG (p 0.0089) but no significant difference in NLR (p 0.347). Metformin nanoparticles could decrease FBG levels and effectively reduce the NLR in the diabetic rat model.
\end{abstract}

Keywords: Diabetes Mellitus; Metformin; Nanoparticles; Neutrophil-Lymphocyte Ratio

\section{INTRODUCTION}

Diabetes mellitus has attracted global attention. Based on data from the International Diabetes Federation (IDF), the prevalence of diabetes mellitus in the world is $1.9 \%$. DM has become the seventh leading cause of death globally. In 2012, diabetes mellitus globally reached 371 million people, with $95 \%$ of it being caused by type 2 diabetes mellitus and the rest being caused by type 1 diabetes mellitus. ${ }^{1}$

According to the World Health Organization (WHO), in 2012, there were 1.5 million deaths caused by diabetes mellitus. WHO estimates that about 422 million people over the age of 18 suffer from diabetes mellitus, with the largest distribution in Southeast Asia and the western Pacific. This condition is chronic and characterized by hyperglycemia, leading to chronic inflammation. Several studies on the relationship of white blood cells as a biomarker of inflammation have found an important role for white blood cell counts in the pathogenesis of insulin resistance. ${ }^{2}$

The leukocyte count is frequently performed to evaluate inflammatory conditions. However, the neutrophil-lymphocyte ratio (NLR) is a new marker of inflammation that offers a more potential marker for 
chronic inflammation. The neutrophil count will increase in chronic inflammatory conditions while the lymphocyte count will decrease. Various studies have also shown that NLR is better than the total leukocyte count. ${ }^{3}$

The high incidence of diabetes mellitus in various regions in Indonesia has raised awareness of the importance of rational treatment in the appropriate management of diabetes mellitus and its complications. Treatment rationales include the accuracy of therapy based on diagnosis, choice of therapy, mode of administration, and evaluation of therapy. The rational use of anti-Diabetes Mellitus drugs has allowed patients to receive treatment according to clinical needs and in the right timeframe at a minimum cost. ${ }^{4}$

The use of metformin in clinical medicine began in 1957 when it was first prescribed as a therapy for diabetes in humans, while Watanabe carried out trials of the effectiveness of the guanide hydrochloride in animal models in early 1918. Although metformin has been on the UK market since 1958, metformin was only approved by the US Food and Drug Administration (FDA) in late 1995. Although this drug has been used regularly for half a century, the exact mechanism of action is still not fully understood. The mechanism of action of metformin is at the complex molecular level. It is known that the main action of metformin is through the intracellular route activation of the AMP protein kinase (AMPK pathway). ${ }^{5}$

Most oral hypoglycemic drugs are available in tablet and capsule form. This conventional dosage has many disadvantages, such as short duration of action due to short half-life, protein binding, gastric irritation, low bioavailability, diarrhea, and water-insoluble. To overcome this limitation, some authors use nanotechnology with the help of a nano-sized package. The application of nanotechnology in medicine is called "Nanomedicine". Nanoparticles are structures that have a size of 1-100 nanometers. It makes the nanoparticles easily penetrate the cell wall so that they are best used as a preparation for bioactive drugs. ${ }^{6}$ The development of a drug delivery system (e.g., nanoparticles) for metformin can reduce the therapeutic dose.

\section{MATERIALS AND METHOD}

This research was a quasi-experimental study with a quantitative approach with a posttest-only control group design. This study aims to assess the effect of metformin nanoparticles in a diabetic rat model by comparing the negative control group, positive control group, and metformin- $\mathrm{HCl}$ therapy group. In this research, the researchers use GDP and RNL as variables. The GDP level is the fasting blood glucose level of rats. The DM model uses a glucometer, which is done before and during the treatment period in all groups. Neutrophil Lymphocyte Ratio (NLR) of diabetic rat model is comparison value between the neutrophil count and the lymphocyte count obtained from the results of the analysis of rat blood samples carried out in a clinical laboratory using a hematology analyzer.

This study was conducted for 28 days, using 16 male Wistar strain white rats (Rattus norvegicus) aged 8 weeks with 250-300 grams of body weight in good health, normal activity, and behavior. Rats were divided into 4 Groups; K1: normal control; K2: negative control (diabetes model); K3: diabetes model treated with metformin $100 \mathrm{mg} / \mathrm{kg} \mathrm{BW}$; K4: diabetes model treated with nanoparticle metformin 100mg/kg BW.

Analysis of blood samples was performed using Pentra Hematology Analyzer. The data were processed using the statistical program GraphPad Prism for Windows, with the Kruskal Wallis non-parametric test and the Mann-Whitney post hoc test.

This study has received permission from the Ethical Committee of the Faculty of Medicine Universitas Tadulako number 6507/UN 28.1.30/KL/2020.

\section{RESULT}

\section{Characteristics of Animal Models}

The samples in this study were male Wistar strain white rats (Rattus norvegicus), 8 weeks old, and weighing 200-250 grams, in good health, with normal activity and behavior. Treatment was carried out by placing the study animal at room temperature, with 12 hours of bright and 12 hours of dark lighting and adequate ventilation. The study animals were fed with standard food and drank water orally. Sixteen rats were used in this study, all of which met the criteria and could be analyzed. Three rats were not analyzed further, 2 died during treatment and 1 did not experience hyperglycemia on the $7^{\text {th }}$ day after STZ induction. Mice that had been induced by STZ and experienced hyperglycemia had several physical characteristics such as dull, matted, glossy hair, less active, and there were signs of inflammation in the orbital area. Based on observations during treatment, the drinking water bottles in hyperglycemic mice seemed to run out more quickly, indicating an increase in drinking water consumption (polydipsia). Rat cages always looked wet, so they must be cleaned every day. It also indicated that the rats have polyuria. 


\section{Body Weight in Diabetic Rat Model}

In the calculation of body weight per treatment group, the mean body weight was $331.29 \pm 35.76$ grams in $\mathrm{K}_{1}, 279.83 \pm 35.67$ grams in K2, $289.4 \pm 27.96$ grams in $\mathrm{K}_{3}$, and $286.75 \pm 13.4$ grams in K4. The total mean of all treatment groups was $298.11 \pm 35.76$ grams. The normality of data distribution was carried out with Shapiro Wilk. As the data were not normally distributed, the Kruskal Wallis non-parametric test was carried out, which showed significant differences between treatment groups ( $p$ 0.0001). The body weights results are illustrated in Figure 1.

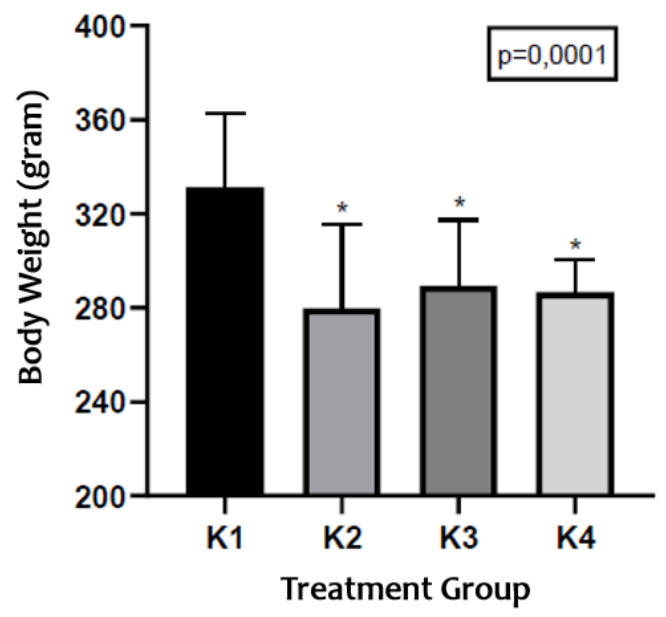

Figure 1. Mean body weight of models $D-7$ to $D+28$ per treatment group

Note: K1: normal control; K2: negative control (diabetes model); K3: diabetes model treated with metformin 100mg/kg BW; K4: diabetes model treated with nanoparticle metformin 100mg/kg BW.

Kruskal Wallis test $\mathrm{p} 0.0001$. Post hoc Mann Whitney Test: K1 vs K2 (p 0.0001), K1 vs K3 ( $p 0.0001$ ), K1 vs K4 (p o.0001), K2 vs K3 (p 0.4192), K2 vs K4 (p 0.5396), K3 vs K4 (p 0.2432). * $p<0.005$ vs K1

Further tests on body weight of models per group were carried out using Mann Whitney with significant differences between $K_{1}$ and $K_{2}$ ( $p$ 0.0001), $K_{1}$ and $K_{3}$ ( $p$ 0.0001), and $K_{1}$ and $K_{4}$ ( $p$ 0.0001). These results indicated significant differences between the bodyweight of the normal group compared to other diabetic groups. Further tests also showed that there were no significant differences between $\mathrm{K}_{2}$ and $\mathrm{K}_{3}$ ( $\mathrm{p}$

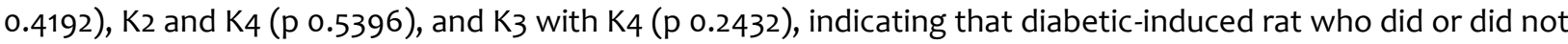
receive therapy, either metformin or nano-metformin, did not experience improvement in body weight to normal values during the study period.

\section{Fasting blood glucose Levels in Diabetic Rat Model}

This study was conducted by inducing STZ intraperitoneally in Wistar rats assigned to $\mathrm{K}_{2}, \mathrm{~K}_{3}$, and $\mathrm{K}_{4}$ groups. Streptozotocin is a diabetogenic substance that damages the pancreatic cells directly on the nitrosourea group and induces an increase in reactive oxygen species (ROS). ${ }^{10}$ The STZ is widely used in animal tests as it increases blood glucose levels by triggering excessively free radical production.

The mean FBC of models per treatment group was $82.75 \pm 6.7$ to $90.5 \pm 12.79$ gram in K1. It indicated that all groups had normal FBG levels $(<126 \mathrm{mg} / \mathrm{dL})$. At the end of the study, the mean FBG levels of models ranged from $79 \pm 15.39$ to $184.75 \pm 76.02$ gram. It meant that the $\mathrm{FBG}$ level of $\mathrm{K}_{1}, \mathrm{~K}_{3}$, and $\mathrm{K}_{4}$ changed during the test, but they fell back to the normal limit. However, for K2, the mean value was still above the normal limit. The FBG level results are illustrated in Figure 2.

The FBG level measurement was carried out to evaluate the effect of metformin therapy by a statistical test of FBG data accumulation from one-week post-therapy $(\mathrm{H}+7)$ until the end of the study $(\mathrm{H}+28)$ per treatment group. The normality test results using Shapiro Wilk showed that the data distribution was not normally distributed. The Kruskal Wallis non-parametric test revealed significant differences between treatment groups (p o.0002). 


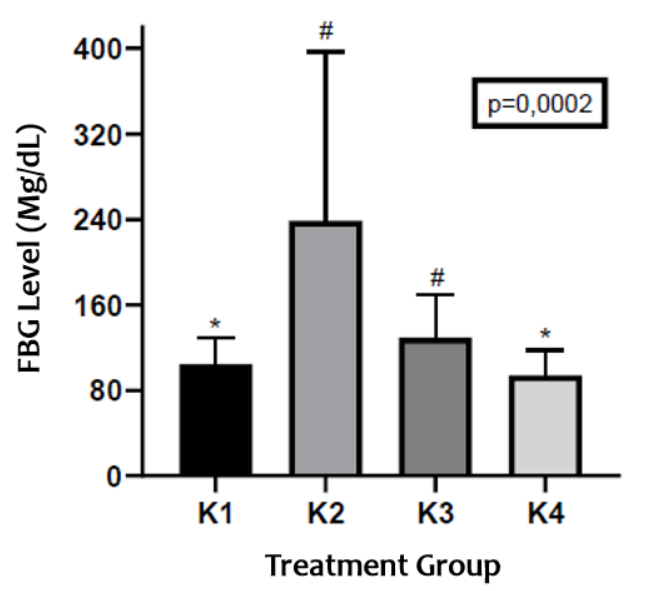

Figure 2. Fasting blood glucose of models $\mathrm{H}+7$ to $\mathrm{H}+28$ per treatment group

Note: K1: normal control; K2: negative control (diabetes model); K3: diabetes model treated with metformin $100 \mathrm{mg} / \mathrm{kg} \mathrm{BW}$; K4: diabetes model treated with nanoparticle metformin 100mg/kg BW.

Kruskal Wallis test showed p 0.0002, Post hoc Mann Whitney test: K1 vs. K2 (p 0.0005$)$, K1 vs. K3 (p $0.1089), K_{1}$ vs. $K_{4}$ ( $\left.p 0.2223\right), K_{2}$ vs. $K_{3}$ ( $\left.p 0.0629\right), K_{2}$ vs. $K_{4}(p 0.0001), K_{3}$ vs. $K_{4}(p 0.0089) . *=p<0.05$ vs $K_{2}$, $\#=p<0.05$ vs K4. Further, the Mann Whitney test showed significant differences in FBG levels between K1 and $K_{2}$ ( $\mathrm{p}$ 0.0005), $\mathrm{K}_{2}$ and $\mathrm{K}_{4}$ ( $\mathrm{p}$ 0.0001), and $\mathrm{K}_{3}$ and $\mathrm{K}_{4}$ ( $\mathrm{p}$ 0.0089). It indicated that the group given with nanometformin therapy (K4) showed an improvement in levels close to the normal limit, with a significant difference between the diabetic group (K2) and metformin therapy group (K3). No significant difference was found between the $\mathrm{K}_{3}$ and normal rat groups (K1). There was a significant difference in the nano-metformin therapy group (K4). It can be concluded that both metformin dosages had a good antihyperglycemic effect, especially the nano-metformin.

\section{Neutrophil Lymphocyte Ratio}

The NLR measurement results showed an effect of metformin administration, both in general and nanoparticle dosage, on the reduction of NLR. It was shown by the total leukocytes and the differential neutrophils and lymphocytes from each group. The range of normal hematologic values varied in individual male and female mice and age groups. ${ }^{13}$ The mean NLR results are illustrated in Figure 3.

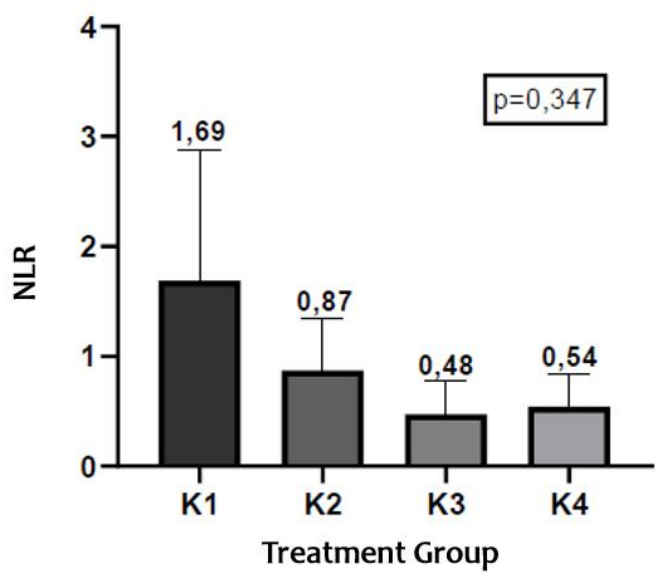

Figure 3. Mean NLR of Models between treatment groups

Note: K1: normal control; K2: negative control (diabetic model); K3: diabetes model treated with metformin 100mg/kg BW; K4: diabetes model treated with nanoparticle metformin 10omg/kg BW.

Kruskal Wallis test $\mathrm{p} 0.0002$. post hoc Mann Whitney test: K1 vs K2 (p 0.0005), K1 vs K3 (p 0.1089), K1 vs $K_{4}$ (p 0.2223), K2 vs K3 (p 0.0629), K2 vs K4 (p 0.0001), K3 vs K4 (p 0.0089). * ${ }^{*}<<0.05$ vs K2, \#=p<0.05 vs K4

Based on the analysis of rat blood samples in the normal control rat group (K1), the mean leukocytes were $3.8 \pm 1.7 \times 10^{3} / \mathrm{mm}^{3}$, absolute neutrophils were $1.94 \pm 0.16$, and absolute lymphocytes were 1.57 \pm 1.2 . In the positive control rat group (K2), the mean leukocytes were $3.5 \pm 0.3 \times 10^{3} / \mathrm{mm}^{3}$, absolute neutrophils were $1.51 \pm$ 0.35 , and absolute lymphocytes were $1.91 \pm 0.64$. In the metformin therapy group (K3), the mean leukocytes 
were $10.45 \pm 12.09 \times 10^{3} / \mathrm{mm}^{3}$, absolute neutrophils were $2.16 \pm 1.97$, and absolute lymphocytes were $7.29 \pm 8.75$. In the nano-metformin therapy group (K4), the mean leukocytes were $6.17 \pm 4.24 \times 10^{3} / \mathrm{mm}^{3}$, absolute neutrophils were $1.7 \pm 1.16$, and absolute lymphocytes were $4.11 \pm 3.53$.

\section{DISCUSSION}

This study was conducted by inducing STZ intraperitoneally in Wistar rats assigned to $\mathrm{K}_{2}, \mathrm{~K}_{3}$, and $\mathrm{K}_{4}$ groups. Streptozotocin is a diabetogenic substance that damages the pancreatic cells directly on the nitrosourea group and induces an increase in reactive oxygen species (ROS). The STZ is widely used in animal tests as it increases blood glucose levels by triggering excessively free radical production.

In this research, the researchers used metformin due to its ability to reduce blood glucose levels without causing weight gain and less incidence of hypoglycemia. ${ }^{9}$ Another study also stated that metformin therapy in obese patients with metabolic syndrome only experienced a weight loss of up to $2.5 \%$. These results fall short of the FDA-mandated limit of the minimum $5 \%$ weight loss that obesity therapy drugs should yield. ${ }^{10}$

The results on the FBG level test align with the theory that the minor mechanism of action of metformin as a biguanide drug is to inhibit gluconeogenesis in the kidneys, slow down glucose absorption in the digestive tract, increase the conversion of glucose to lactate by enterocytes, direct stimulation of glycolysis in tissues, increase glucose uptake from the blood, and decrease plasma glucagon levels. The effect of biguanide in lowering blood glucose is independent of pancreatic beta cells. Patients with type 2 diabetes will show a significant reduction in fasting hyperglycemia and postprandial hyperglycemia after biguanide administration. ${ }^{11,12}$

The NLR values in the K1 group were $0.85-2.53$, with a mean NLR of 1.69. The result of K1 was higher than other treatment groups as one of the mice in the group had a high neutrophil count value. It could be influenced by several factors, such as the amount and type of feed, cleanliness of the cage, the stress conditions of the animals, the possibility of an early infection, thus influencing the increase in the mean NLR.

Meanwhile, in the K2 group, the NLR values were 1.21 - 0.53 with a mean NLR of 0.87 , which according to our assumptions, was still within the normal range, where hyperglycemia conditions should trigger inflammation characterized by an increase in the number of neutrophils as a mediator of inflammation. Hence, an increase in NLR is equal to or possibly more than the K1 group. It occurred due to the unknown initial NLR value and the possibility of neutropenia in study models.

In the $\mathrm{K}_{3}$ group, the NLR values were $0.69-0.26$, with a mean NLR of 0.48 . In the K4 group, the NLR values were $0.22-0.81$, with a mean NLR of 0.54 . The mean NLR between $\mathrm{K}_{3}$ and $\mathrm{K} 4$ only showed a slight difference, and both of them had the lowest mean NLR compared to other treatment groups. The result of the Kruskal-Wallis test showed no significant differences in the mean RNL of each group ( $\mathrm{p} 0.347$ ).

In the evidence, metformin could reduce subclinical inflammation as measured by NLR. It is noteworthy that supported previous reports that metformin could suppress markers of inflammation such as hsCRP in prediabetic individuals and TNF in insulin-resistant individuals. The NLR had recently been identified as a biomarker and the predictor of all-cause mortality and cardiovascular events, while previous studies demonstrated a substantial beneficial effect of metformin therapy on cardiovascular outcomes. . $^{14,15,16}$ In this research, the researchers found that suppressing chronic inflammation by metformin might contribute to the difference in diabetic rat model outcomes. Metformin directly affects inflammation, including effects on NF-KB signaling and differentiation of monocytes into macrophages, ${ }^{17,18}$, as well as suppressing proinflammatory cytokines from these macrophages. In line with this, metformin suppresses the NLR in type 2 diabetes.19-20

The test's limitation was the absence of the initial (pre-test) value of the NLR of each treatment group so that the hematological value of each rat in each group at the beginning of the study and whether there were any previous infections remained unidentified. Furthermore, the short study period of 28 days is also a limitation, where the results may be different if further tests are carried out with a longer study time.

\section{CONCLUSION}

The conclusion is that metformin nanoparticles could reduce Fasting Blood Glucose levels periodically to below normal limits, could maintain the NLR value but are not significantly different, and has a better antihyperglycemic effect than metformin- $\mathrm{HCl}$ preparations. Both metformin preparations could reduce the Neutrophil-Lymphocyte Ratio through an antihyperglycemic effect.

\section{ACKNOWLEDGMENT}

The researchers would like to thank Lembaga Penelitian dan Pengabdian Masyarakat (LPPM) Universitas Tadulako and Faculty of Medicine Universitas Tadulako for the financial support from DIPA FK 2020. 


\section{CONFLICT OF INTEREST}

There are no conflicts of interest in this research.

\section{REFERENCES}

1. International Diabetes Federation. 2013. IDF Diabetes Atlas sixth edition. IDF: Brussels.

2. World Health Organization. (2014). Diabetes Mellitus. WHO News: Fact Sheet. WHO: Geneva.

3. Wibisana KA, Subekti I, Antono D, dan Nugroho P. Hubungan antara Rasio Neutrofil Limfosit dengan Kejadian Penyakit Arteri Perifer Ekstremitas Bawah pada Penyandang Diabetes Melitus Tipe 2. Jurnal Penyakit Dalam Indonesia. 2018:5(4)184-188. http://dx.doi.org/10.7454/jpdi.v5i4.227

4. Hongdiyanto A, dan Yamlean PVY. Evaluasi Kerasionalan Pengobatan Diabetes Melitus Tipe 2 pada Pasien Rawat Inap di RSUP Prof. Dr. R. D. Kandou Manado Tahun 2013. Pharmacon. 2014:3(2):77-86. https://doi.org/10.35799/pha.3.2014.4775

5. Janić M, Volčanšek Š, Lunder M, and Janež A. 2017. Metformin: from mechanisms of action to advanced clinical use. Zdrav Vestn. 2017:86:138-1457. https://doi.org/10.6016/ZdravVestn.1503

6. Alhalmi A, Alzubaidi N, and Abdulmalik W. Current Advances in Nanotechnology for Delivery of Anti-Diabetic Drugs: A Review. Int J Pharmacog. 2018:5(1):1-7. https://doi.org/10.13040/IJPSR.0975-8232.IJP.5(1).1-07

7. Pereira A, Brito G, Lima M, Silva Júnior A, Silva E, de Rezende A, et al. Metformin Hydrochloride-Loaded PLGA Nanoparticle in Periodontal Disease Experimental Model Using Diabetic Rats. Int J Mol Sci. 2018:19(11)3488. https://doi.org/10.3390/ijms19113488

8. Hasanah A. Efek Jus Bawang Bombay (Alium cepa Linn.) terhadap Mortalitas Spermatozoa Mencit yang Diinduksi Streptozotocin (STZ). Saintika Medika: Jurnal Ilmu Kesehatan dan Kedokteran Keluarga. 2015;11(2):92101. https://doi.org/10.22219/sm.v11i2.4203

9. Putra RJS, Achmad A, dan Rachma H. Kejadian Efek Samping Potensial Terapi Obat Anti Diabetes Pasien Diabetes Melitus Berdasarkan Algoritma Naranjo. Pharmeceutical Journal of Indonesia. 2017:2(2):45-50.

10. Zufry H. Terapi Farmakologis pada Obesitas. Jurnal Kedokteran Syiah Kuala. 2010:10(3):157-168.

11. Saputra TN, Suartha N, dan Dharmayudha OGAA. Agen Diabetogenik Streptozotocin untuk Membuat Tikus Putih Jantan Diabetes Melitus. Buletin Veteriner Udayana. 2018;10(2):116-121. https://doi.org/10.24843/bulvet.2018.v10.i02.p02

12. Katzung B.G. Farmakologi Dasar dan Klinik. EGC: Jakarta. 2016.

13. Fitria L, dan Sarto M. Profil Hematologi Tikus (Rattus norvegicus Berkenhout, 1769) Galur Wistar Jantan dan Betina Umur 4, 6, dan 8 Minggu. Biogenesis. 2014:2, 2(2):94-100. https://doi.org/10.24843/bulvet.2018.v10.i02.p02

14. Cameron AR, Morrison VL, Levin D, Mohan M, Forteath C, Beall C, et al. Antiinflamatory Effect of Metformin Irrespective of Diabetes Status. Circ Res. 2016. 1(19):652-665. https://doi.org/10.1161/CIRCRESAHA.116.308445

15. Wang X, Zhang G, Jiang X, Zhu H, Lu Z, and Xu L. Neutrophil to Lymphocyte Ratio in Relation to Risk of AllCause Mortality and Cardiovascular Events among Patients undergoing Angiopraphy or Cardiac Revascularization: A Meta-Analysis of Observational Studies. Atherosclerosis. 2014: 234:206-213. https://doi.org/10.1016/j.atherosclerosis.2014.03.003

16. Ip B, Clifone N, Zhu M, Kuchibhatla RA, Zer M, McDonnell M, et al. An Inflammatory T Cell Signature Predicts Obesity Associated Type 2 Diabetes. J. Immunol, 2015; 1-94: 121-122.

17. Wong AKF, Symon R, Alzadjali MA, Ang DSC, Ogston S, Choy AM, et al. The effect of metformin on insulin resistance and exercise parameters in patients with heart failure. Eruopean Journal of Heart Failure. 2012:14:1303. 1310. https://doi.org/10.1093/eurjhf/hfs106

18. Vasamsetti SB, Karnevewar S, Kanugula AK, Thatipali AR, Kumar JM, Kotamraju S. Metformin Inhibits Monocyte to Macrophage Differentiation Via AMPK Mediated Inhibition of STAT3 Activation: Potential Role in Atherosclerosis. Diabetes. 2015; 64:2028-2041. https://doi.org/10.2337/db14-1225

19. Rena G, Hardie G, and Pearson ER. The Mechanism of Action of Metformin. Diabetologia. 2017; 601:15771585. https://doi.org/10.1007/s00125-017-4342-z

20. Griffin SJ, Leaver JK, Irving GJ. Impact of Metformin on Cardiovascular Disease: A Meta-analysis of Randomised Trials among People with Type 2 Diabetes. Diabetologia. 2017; 60(9):1620-1629. https://doi.org/10.1007/s00125-017. $\underline{4337-9}$ 